\title{
Tricks of the trade
}

\author{
Pulo do gato \\ Laura Silveira-Moriyama ${ }^{1}$, Andrew J. Lees²
}

\begin{abstract}
${ }^{1}$ Reta Lila Weston Institute of Neurological Studies, UCL Institute of Neurology, London, UK; Child Neurology Unit, Department of Neurology, University of Campinas (UNICAMP), Campinas, Brazil;

${ }^{2}$ Child Neurology Unit, Department of Neurology, University of Campinas (UNICAMP), Campinas SP, Brazil.
\end{abstract}

\section{Correspondence:}

Laura Silveira-Moriyama Reta Lila Weston Institute of Neurological Studies, UCL Institute of Neurology

1 Wakefield street, WC1N 1PJ,

London - UK

E-mail: laura.moriyama@ucl.ac.uk

Conflict of interest:

There is no conflict of interest to declare.

Received 08 February 2012 Accepted 15 February 2012
$\mathrm{T}$ he Editorial Board of Arquivos de Neuro-Psiquiatria is pleased to announce the opening of a new section, which is entitled "Tricks of the trade/Pulo do gato". It provides articles from invited authorities in various fields of Neurology who are willing to share their expertise, especially international experts who are keen on collaborations with Latin-American Neuroscience and Clinical Neurology. To open the section we invited Doctor Sarosh Irani and Professor Angela Vincent from Oxford to write a practical update on the exciting field of autoimmune encephalitis.

Professor Angela Vincent has major contributions to the understanding and the diagnosis of various antibody-mediated diseases of the central and peripheral nervous system. She did extensive work on myasthenia gravis, including the discovery of $\mathrm{MuSK}^{1}$ antibodies and the development of methods to detect the presence of low-affinity IgG anti-acetylcholine receptor antibodies ${ }^{2}$. She also described the association of VGKC-complex antibodies with Morvan's fibrillary chorea ${ }^{3,4}$, and she later defined the clinical manifestations in cases of limbic encephalitis associated with the same antibodies ${ }^{5}$, and subsequently the actual targets of the antibodies in the brain ${ }^{6}$. Amongst other things, Vincent also described a novel glycine receptor antibody in patients with progressive encephalomyelitis with rigidity and myoclonus?

In the first "Tricks of the trade", the invited ones explain the main advances on the understanding of the pathophysiology of the autoimmune encephalitis and pinpoint the major clinical features that differentiate the encephalitis associated with each known antibody. Autoimmune encephalitis accounts for a significant proportion of the cases suspected to have viral encephalitis, which are negative for the main viral aetiologies, including the classical cases of limbic encephalitis. Most importantly, when readily identified they respond successfully to immunotherapies. Therefore, it is of interest to the general neurologist as much as it is to the specialist to understand the developments in this rapidly changing field.

\section{References}

1. Hoch W, McConville J, Helms S, Newsom-Davis J, Melms A, Vincent A. Auto-antibodies to the receptor tyrosine kinase MuSK in patients with myasthenia gravis without acetylcholine receptor antibodies. Nat Med 2001;7:365-368.

2. Leite MI, Jacob S, Viegas S, et al. IgG1 antibodies to acetylcholine receptors in 'seronegative' myasthenia gravis. Brain 2008;131:1940-1952.

3. Barber PA, Anderson NE, Vincent A. Morvan's syndrome associated with voltage-gated $\mathrm{K}+$ channel antibodies. Neurology 2000:54:771-772.

4. Liguori R, Vincent A, Clover L, et al. Morvan's syndrome: peripheral and central nervous system and cardiac involvement with antibodies to voltage-gated potassium channels. Brain 2001;124:2417-2426.

5. Vincent A, Buckley C, Schott JM, et al. Potassium channel antibodyassociated encephalopathy: a potentially immunotherapy-responsive form of limbic encephalitis. Brain 2004;127:701-712.

6. Irani SR, Alexander S, Waters P, et al. Antibodies to Kv1 potassium channel-complex proteins leucine-rich, glioma inactivated 1 protein and contactin-associated protein-2 in limbic encephalitis, Morvan's syndrome and acquired neuromyotonia. Brain 2010;133:2734-2748.

7. HutchinsonM,Waters P,McHughJ,etal.Progressiveencephalomyelitis, rigidity, and myoclonus: a novel glycine receptor antibody. Neurology 2008;71:1291-1292. 